\title{
Effects of percolating water with graduated acidity upon the leaching of nutrients and the changes in some chemical properties of mineral soils
}

\author{
František Haman \\ University of Helsinki, Department of Agricultural Chemistry ${ }^{\mathbf{1}}$ )
}

\begin{abstract}
Leaching of nutrients and the changes in some chemical properties of surface soil layer treated with solutions of gradual acidity were followed under laboratory conditions. The 25-cm-high columns of three soils, (A - fine sand, B - loam, C - clay loam), placed in plastic tubes were treated with deionized water $(\mathrm{pH} 6)$ and with three solutions $(\mathrm{pH} 5, \mathrm{pH} 4, \mathrm{pH} 3)$ of sulphuric acid. The washed out nutrients were determined in the leachates collected into plastic bags. The largest amount of nitrogen found in the leachates was in the form of nitrate and this was proportional to the content of organic matter in the soils. The leached amount of $\mathrm{NH}_{4}-\mathrm{N}$ was considerably lower and like potassium it was negatively dependent upon the clay content in the soils. The concentrations of $\mathrm{K}$, $\mathrm{Ca}$ and $\mathrm{Mg}$ in the leachates rose in relation to the declining $\mathrm{pH}$ of percolating solutions. Especially in soil A, acid solutions of $\mathrm{pH} 5$ (and lower) washed out very effectively the cations. Soils B and C (with a higher content of clay particles) showed a higher resistance to $\mathrm{K}, \mathrm{Ca}$ and $\mathrm{Mg}$ leaching. The acidified water influenced even the $\mathrm{pH}$ of the surface layer $(0-7,5 \mathrm{~cm})$ of soils in the columns. The most marked decrease in $\mathrm{pH}$ values was found in soil $\mathrm{A}$ after an application of the solution with $\mathrm{pH} 3$. A decrease in the content of basic cations $(\mathrm{Ca}$ and $\mathrm{Mg}$ ) was parallel to the acidification of the upper layer of the soils.
\end{abstract}

\section{Introduction}

In the majority of industrialized European countries air pollution has been one of the most rapidly spreading phenomena in recent years. Air pollution has unfavourable effects upon other components of the environment, especially upon biological systems, soil, and surface water. The volume of industrial immissions is now rather extensive; apart from a million tons of flying ash, a lot of gaseous immissions, mainly sulphur dioxide, get into the atmosphere. Sulphur dioxide is very dangerous for all living organisms. It enters as a very dangerous compound of an acid character the soil with precipitations as well as the soil surface owing to a certain sorption capacity

1) Present address: Department of Agricultural Chemistry and Plant Nutrition, University of Agriculture, Brno, Czechoslovakia. 
in it. Normal rain water balanced with carbon dioxide in the air shows a $\mathrm{pH}$ of approximately 5.7. However, in many European countries it has been noted that the acidity of rainfalls has increased considerably during the last twenty years. According to ODÉN (1968), the acidity of rain water increased 100 -fold in central Europe within the period between 1958 and 1965 . According to other authors, there was a 200 -fold increase in the acidity of precipitations in some parts of Scandinavia in comparison with 1956. In some localities of Western Europe and Scandinavia, the average annual values of the $\mathrm{pH}$ of rain water dropped as low as 4.0 in 1968, in the Netherlands this value was even lower.

In areas afflicted by these acid precipitations, a process of soil acidization is taking place. This situation has occurred, for example, in some parts of Sweden and Norway where dangerous acid clouds appear blown by winds from Western and Central Europe. Therefore, the acidization of surface waters in lakes and rivers is increasingly intensive here. But even in soil, WIKLANDER (1973) found that the $\mathrm{pH}$ and the saturation of soil with basic ions decreased due to precipitations containing sulphuric, nitric and chloric acids.

In this paper are presented the results of an experiment which was carried out according to a suggestion of Prof. A. Kaila, Head of the Department of Agricultural Chemistry, University of Helsinki, to study the effects of gradually acid waters upon a leaching of nutrients and changes in chemical properties of some Finnish mineral soils.

\section{Materials and methods}

The model experiment was carried out under laboratory conditions. Samples of arable layers of three mineral soils (collected near Helsinki in Viikki) were used for this investigation: A-fine sand, B-loam, C-clay loam. The following characteristics were found in the tested soils before the establishment of the trial (Table 1).

Table 1. Characteristics of the experimental soils.

\begin{tabular}{|c|c|c|c|c|c|c|c|}
\hline \multirow{3}{*}{ Sample } & \multirow{3}{*}{ Soil type } & \multirow{3}{*}{$\begin{array}{c}\text { Org. C } \\
\%\end{array}$} & \multirow{3}{*}{$\mathrm{pH} / \mathrm{CaCl}_{2}$} & \multicolumn{2}{|c|}{ Extract $1 \mathrm{n} \mathrm{KCl}$} & \multicolumn{2}{|c|}{ Extract $0.5 \mathrm{n} \mathrm{K}_{2} \mathrm{SO}_{4}$} \\
\hline & & & & $\mathrm{Ca}$ & $\mathrm{Mg}$ & $\mathrm{N}-\mathrm{NO}_{3}$ & $\mathrm{~N}-\mathrm{NH}_{4}$ \\
\hline & & & & $\mathrm{mg} / 100 \mathrm{~g}$ & $\mathrm{mg} / 100 \mathrm{~g}$ & $\mathrm{mg} / 1000 \mathrm{~g}$ & $\mathrm{mg} / 1000 \mathrm{~g}$ \\
\hline A & fine sand ........ & 1.5 & 5.80 & 97.0 & 6.65 & 2.00 & 4.10 \\
\hline B & loam …........... & 1.0 & 5.92 & 113.0 & 11.20 & 4.40 & 3.00 \\
\hline $\mathrm{C}$ & clay loam ......... & 1.8 & 5.92 & 208.0 & 40.00 & 4.20 & 11.00 \\
\hline
\end{tabular}

Air dried and ground soils (with a $2 \mathrm{~mm}$ sieve) were placed into plastic tubes with a diameter of about $5.5 \mathrm{~cm}$. The height of the soil column was $25 \mathrm{~cm}$. The plastic tubes were perforated at the bottom of each column. Small plastic bags were attached to the lower part of the columns to col- 
lect the percolating solutions. After the soils in the columns bad been moistened to field capacity, each column received (during five days) $300 \mathrm{ml}$ of the following diluted solutions:

I. deionized water - pH 6 (buffered by the Beckman 3581 Buffer Solution - exact $\mathrm{pH}$ 6.08)

II. solution $-\mathrm{pH} 5\left(0.00001 \mathrm{n}_{2} \mathrm{SO}_{4}-\right.$ exact $\left.\mathrm{pH} 5.20\right)$

III. solution $-\mathrm{pH} 4\left(0.0001 \mathrm{n} \mathrm{H}_{2} \mathrm{SO}_{4}\right.$ - exact $\left.\mathrm{pH} 4.10\right)$

IV. solution $-\mathrm{pH} 3\left(0.001 \mathrm{n} \mathrm{H}_{2} \mathrm{SO}_{4}-\right.$ exact $\left.\mathrm{pH} 3.08\right)$

Three columns of each soil were dressed by the same solution.

Three days later (after the last irrigation) the percolated solutions in the plastic bags were measured and analysed for $\mathrm{NO}_{3}-\mathrm{N}, \mathrm{NH}_{4}-\mathrm{N}$ (both with using specific ion electrodes), $\mathrm{K}$ (flame photometer), $\mathrm{Ca}$ and $\mathrm{Mg}$ (atomic absorption spectrophotometer) and $\mathrm{pH}$. The upper part of the columns was cut into two $7.5 \mathrm{~cm}$ thick layers. The soil layers were allowed to dry and were then analysed separately in the same way for $\mathrm{NO}_{3}-\mathrm{N}$ and $\mathrm{NH}_{4}-\mathrm{N}$ (from an $0.5 \mathrm{n} \mathrm{K}_{2} \mathrm{SO}_{4}$ extract), $\mathrm{Ca}$ and $\mathrm{Mg}$ (from an extract of $1 \mathrm{n} \mathrm{KCl}$ ) and $\mathrm{pH}$ (measured in $0.01 \mathrm{M} \mathrm{CaCl}_{2}$ ).

\section{Results}

Analyses of collected leachates

As shown in Table 2, the major part of the nitrogen washed out by percolating water from the soil was in the form of nitrate ions $\left(\mathrm{NO}^{3}\right)$. The amount of nitrates washed off by percolating solutions from individual types of soils was positively correlated with the amount of organic substances occurring in these soils (see percentages of organic carbon in Table 1). There was no such correlation with regard to ammonium-N; however, a significantly higher amount of this form of nitrogen was washed off from fine sand (soil A) which showed a very low content of clay particles. Different $\mathrm{pH}$ values of leaching solutions did not influence unambiguously the concentration of $\mathrm{NO}_{3}-\mathrm{N}$ in collected leachates from all the tested soils (Fig. 1). In soils A and $\mathrm{B}$ the largest amounts of nitrates were washed out with a solution of $\mathrm{pH}$ 4. In soil C (clay loam) there was an apparent tendency for the concentration of nitrates in extracts to decrease with the increasing acidity of percolating water.

The leachates from the more acid soil A (fine sand) contained the largest amounts of potassium, while those from soil C - rich in clay particles - showed the lowest content of this element (Table 2). Calcium and magnesium showed reversed values which depended upon their initial contents in the experimental soils (see Table 1). The increasing acidity of the leaching solutions resulted in an increased concentration of all these cations $(\mathrm{K}, \mathrm{Ca}$ and $\mathrm{Mg}$ ) in the extracts (Fig. 1). Especially in soil A, acid solutions of $\mathrm{pH} 5$ (and lower) washed out very effectively the cations. Soils B and C, with a higher content of clay particles, showed relatively higher resistance to $\mathrm{K}, \mathrm{Ca}$ and $\mathrm{Mg}$ leaching, usually up to $\mathrm{pH} 4$. 
Table 2. Results of analyses of percolated solutions (average values in $\mathrm{mg} / 1000 \mathrm{ml}$ )

A - fine sand

\begin{tabular}{|c|c|c|c|c|c|}
\hline \multirow{2}{*}{$\begin{array}{l}\text { Irrigating } \\
\text { solution }\end{array}$} & \multicolumn{2}{|c|}{$\mathrm{N}$} & \multirow[b]{2}{*}{$\mathrm{K}$} & \multirow[b]{2}{*}{$\mathrm{Ca}$} & \multirow[b]{2}{*}{$\mathrm{Mg}$} \\
\hline & $\mathrm{NO}_{3}$ & $\overline{\mathrm{NH}_{4}}$ & & & \\
\hline I pH $6 \ldots \ldots \ldots \ldots \ldots . . . . .$. & 8.00 & 0.018 & 4.55 & 15.51 & 1.08 \\
\hline II pH $5 \ldots \ldots \ldots \ldots \ldots . . . . .$. & 8.84 & 0.016 & 5.02 & 16.86 & 1.18 \\
\hline III pH $4 \ldots \ldots \ldots \ldots \ldots . . . . . .$. & 8.89 & 0.024 & 5.16 & 17.78 & 1.22 \\
\hline IV pH $3 \ldots \ldots \ldots \ldots \ldots . . . . .$. & 8.58 & 0.018 & 5.24 & 19.45 & 1.35 \\
\hline
\end{tabular}

B - loam

\begin{tabular}{|c|c|c|c|c|c|}
\hline I pH $6 \ldots \ldots \ldots \ldots \ldots . . . . .$. & 4.75 & 0.010 & 4.35 & 19.57 & 2.85 \\
\hline II pH $5 \ldots \ldots \ldots \ldots \ldots . . . . .$. & 4.88 & 0.006 & 4.45 & 19.84 & 2.93 \\
\hline III $\mathrm{pH} 4 \ldots \ldots \ldots \ldots \ldots . . . . . . .$. & 5.10 & 0.010 & 4.66 & 19.96 & 2.96 \\
\hline IV pH $3 \ldots \ldots \ldots \ldots . . . . . . . .$. & 4.95 & 0.006 & 4.83 & 21.00 & 3.05 \\
\hline
\end{tabular}

C - clay loam

\begin{tabular}{|c|c|c|c|c|c|}
\hline I pH $6 \ldots \ldots \ldots \ldots \ldots . . . . .$. & 13.32 & 0.008 & 4.16 & 20.53 & 5.58 \\
\hline II pH $5 \ldots \ldots \ldots \ldots \ldots . . . . . . .$. & 11.79 & 0.008 & 4.14 & 20.63 & 5.57 \\
\hline III $\mathrm{pH} 4 \ldots \ldots \ldots \ldots \ldots . . . . .$. & 10.61 & 0.008 & 4.21 & 20.67 & 5.57 \\
\hline IV $\mathrm{pH} 3 \ldots \ldots \ldots \ldots \ldots . . . . . .$. & 10.32 & 0.011 & 4.51 & 21.74 & 5.82 \\
\hline
\end{tabular}

$\%$
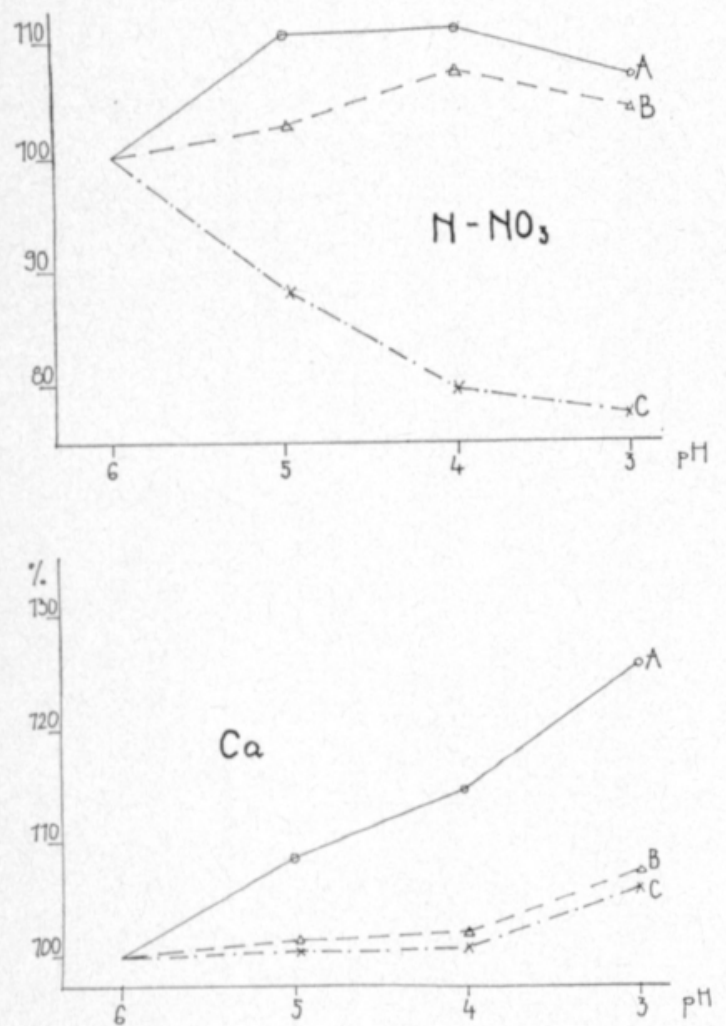
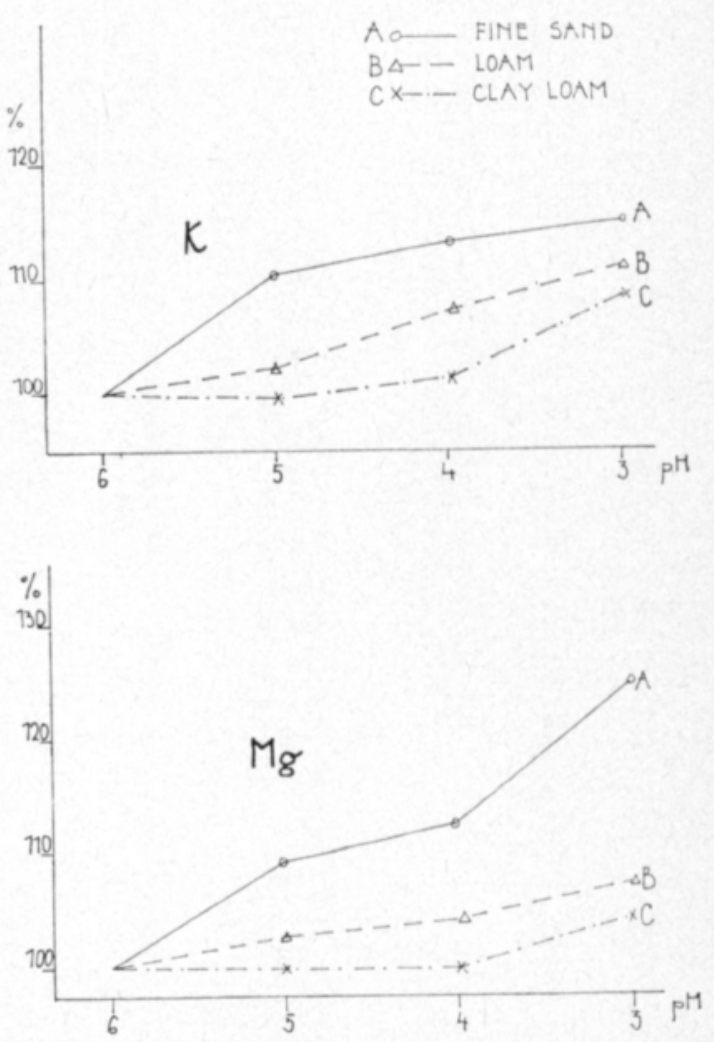

Figure 1. Leaching of nutrients by percolating water in relation to $\mathrm{pH}$ (in relative values $-\%$ ). 
The final $\mathrm{pH}$ values of the collected extracts were always higher than the original ones; this was due to considerable amounts of extracted cations. However, different effects of individual soils as well as of initial $\mathrm{pH}$ values in percolating solutions did not show too much in the final $\mathrm{pH}$ values of the collected leachates.

\section{Analyses of soil samples}

The $\mathrm{pH}$ values of soil samples measured at the end of the experiment (Table 3) indicate an acidifiant effect of irrigating solutions with a lower $\mathrm{pH}$; this effect was manifested especially in the upper soil layer (0 to 7.5 $\mathrm{cm}$ ) even during the short term experiment. The most marked $\mathrm{pH}$ decrease was observed in soil $\mathrm{A}$ after the action of solution with $\mathrm{pH} 3$.

Table 3. Results of analyses of soil samples (average values).

A - fine sand

\begin{tabular}{|c|c|c|c|c|c|c|c|}
\hline \multicolumn{3}{|c|}{ Treatment } & \multirow{2}{*}{$\mathrm{pH}$} & $\mathrm{N}-\mathrm{NO}_{3}$ & $\mathrm{~N}-\mathrm{NH}_{4}$ & \multicolumn{2}{|l|}{$\mathrm{Ca}$} \\
\hline No. & solution & layer & & $\mathrm{mg} /$ & $0 \mathrm{~g}$ & $\mathrm{mg}$ & $g$ \\
\hline \multirow[t]{2}{*}{ I } & pH 6 & a & 5.81 & 2.80 & 5.20 & 101.70 & 6.73 \\
\hline & & b & 5.83 & 2.90 & 5.30 & 103.70 & 6.89 \\
\hline \multirow[t]{2}{*}{ II } & pH 5 & $\mathbf{a}$ & 5.82 & 2.70 & 8.20 & - & - \\
\hline & & $\mathbf{b}$ & 5.85 & 2.70 & 8.20 & - & - \\
\hline \multirow[t]{2}{*}{ III } & $\mathrm{pH} 4$ & $\mathbf{a}$ & 5.80 & 2.90 & 13.60 & - & - \\
\hline & & b & 5.85 & 3.00 & 13.60 & - & - \\
\hline \multirow[t]{2}{*}{ IV } & pH 3 & a & 5.72 & 3.10 & 15.00 & 100.70 & 6.70 \\
\hline & & b & 5.83 & 3.00 & 14.90 & 103.00 & 6.87 \\
\hline
\end{tabular}

B - loam

\begin{tabular}{|c|c|c|c|c|c|c|c|}
\hline \multirow[t]{2}{*}{ I } & pH 6 & $\mathrm{a}$ & 6.02 & 4.50 & 3.10 & 111.30 & 10.75 \\
\hline & & b & 6.07 & 4.30 & 3.20 & 114.70 & 11.20 \\
\hline \multirow[t]{2}{*}{ II } & pH 5 & $\mathrm{a}$ & 6.02 & 4.10 & 3.20 & - & - \\
\hline & & b & 6.05 & 4.20 & 2.90 & - & - \\
\hline \multirow[t]{2}{*}{ III } & pH 4 & a & 6.03 & 3.90 & 3.30 & - & - \\
\hline & & b & 6.05 & 4.00 & 3.30 & - & - \\
\hline \multirow[t]{2}{*}{ IV } & pH 3 & a & 5.98 & 4.80 & 4.60 & 109.30 & 10.60 \\
\hline & & b & 6.02 & 4.90 & 3.80 & 113.30 & 11.20 \\
\hline
\end{tabular}

C - clay loam

\begin{tabular}{|c|c|c|c|c|c|c|c|}
\hline \multirow[t]{2}{*}{ I } & $\mathrm{pH} 6$ & a & 5.95 & 3.40 & 3.90 & 212.00 & 39.10 \\
\hline & & b & 5.92 & 3.70 & 3.70 & 212.00 & 39.70 \\
\hline \multirow[t]{2}{*}{ II } & pH 5 & $\mathrm{a}$ & 5.94 & 3.50 & 3.90 & - & - \\
\hline & & b & 5.95 & 3.60 & 3.80 & - & - \\
\hline \multirow[t]{2}{*}{ III } & $\mathrm{pH} 4$ & a & 5.92 & 3.80 & 4.20 & - & - \\
\hline & & b & 5.95 & 4.00 & 3.90 & - & - \\
\hline \multirow[t]{2}{*}{ IV } & pH 3 & $\mathrm{a}$ & 5.89 & 3.70 & 5.10 & 207.30 & 38.70 \\
\hline & & b & 5.95 & 3.60 & 4.90 & 210.00 & 38.80 \\
\hline
\end{tabular}

\footnotetext{
a... layer $0-7.5 \mathrm{~cm}$

b... layer $7.5-15 \mathrm{~cm}$
} 
At the end of the experiment, the content of nitrates in soils A and B was higher than in the original samples while in soil $\mathrm{C}$ it was only slightly lower. This observation also indicates an intensive nitrification in these soils during the whole experiment as well as their simultaneous extraction with percolating solutions. The increasing acidity of these solutions did not show any significant effects upon the $\mathrm{NO}_{3}-\mathrm{N}$ content in the analyzed layers of experimental soils.

The highest amount of $\mathrm{NH}_{4}-\mathrm{N}$ was found in soil $\mathrm{A}$ at the end of the experiment; this was the soil from which the greatest amount of this form of nitrogen had been washed out (Table 2). The content of $\mathrm{NH}_{4}-\mathrm{N}$ increased in all soils with the decreasing $\mathrm{pH}$ of the percolating solutions. In soil $\mathrm{A}$ this trend was evident within the whole $\mathrm{pH}$ range of the solutions investigated; in soils $\mathrm{B}$ and $\mathrm{C}$ it was markedly manifested as late as after the action of the $\mathrm{pH}$ 3 solution.

The relationships between the $\mathrm{pH}$ values and the $\mathrm{NO}_{3}-\mathrm{N}$ and $\mathrm{NH}_{4}-\mathrm{N}$ contents in soil samples (layers) were evaluated by linear correlation analysis. The correlation coefficients (Table 4) show significant positive dependence between the $\mathrm{pH}$ values and nitrates. On the other hand, significant negative correlations were manifested between the $\mathrm{pH}$ and amonium nitrogen and between both forms of nitrogen in soil.

Table 4. Correlation coefficients for relationships between $\mathrm{pH}$ and the forms of nitrogen in treated soils.

\begin{tabular}{lrr}
\hline & $\mathrm{pH}$ & $\mathrm{NO}_{3}-\mathrm{N}$ \\
\hline $\mathrm{NO}_{3}-\mathrm{N}$ & $0.84^{* * *}$ & \\
$\mathrm{NH}_{4}-\mathrm{N}$ & $-0.78^{* *}$ & $-0.64^{* *}$ \\
\hline
\end{tabular}

The $\mathrm{Ca}$ and $\mathrm{Mg}$ contents in upper layers of experimental soils were estimated only after the treating with deionized water (I. $-\mathrm{pH} 6$ ) and the most acid solution (IV. - pH 3). The increased concentrations of these elements in columns irrigated with distilled water (as compared with original values) resulted probably from the mineralization of organic matter and, eventually, an increased solubility of hardly soluble calcareous compounds. In all three soils, however, the contents of calcium and magnesium had decreased due to the action of acid leaching solutions with $\mathrm{pH} 3$; this demonstrated a more intensive movement of $\mathrm{Ca}$ and $\mathrm{Mg}$ within the soil profile and, thus, their increased extraction.

\section{Discussion}

In this experiment conditions favourable for the development of microbial activity. (i.e. an optimum temperature of approximately $25^{\circ} \mathrm{C}$ and a high soil humidity) enabled an intensive formation of nitrates in all three experimental soils (A, B, and C). In consequence the major part of the nitrogen extracted from these soils by applied solutions was in the form of $\mathrm{NO}_{3}-\mathrm{N}$. It should be mentioned that no fertilizers were used in this experiment. This 
means that the contamination of surface and ground water with nitrates may result not only from the application of nitrogen fertilizers but also from an increased microbial activity of the soil provided that there are favourable conditions for the growth of microorganisms, i.e. a high content of organic matter, an optimum ratio between water and air in the soil, and an adequate temperature (GoH, 1972). The $\mathrm{pH}$ value of percolating water may show different effects upon the leaching of nitrogen and the occurrence of various forms of nitrogen compounds in soil depending upon its kind and type.

Both the potassium and the $\mathrm{NH}_{4}^{+}$ions were washed out from experimental soils in correlation with the content of clay particles and $\mathrm{pH}$ in soils. Korkman (1970) also observed a negative correlation between the clay content in soil and the potassium and $\mathrm{NH}_{4}^{+}$movement from fertilizers applied. This observation coincides with opinions published by STANFORD (1948) and KaILA (1965), according to which the clay content has a significant effect on the fixation of potassium in soils. In this experiment, however, it has been demonstrated that the clay content in soil has an even more significant effect upon the wash-out of bivalent cations $\mathrm{Ca}$ and $\mathrm{Mg}$, especially in interaction with an increasing acidity of percolating water. In soil A, even an irrigating solution with $\mathrm{pH} 5$ caused appreciable leaching of bivalent cations. A higher content of clay particles in soil B and, especially, in soil C prevented very effectively the wash-out of calcium and magnesium by acid percolating solutions up to $\mathrm{pH} 4$. If a leaching solution with $\mathrm{pH} 3$ was applied, a marked decrease in the $\mathrm{Ca}$ and $\mathrm{Mg}$ contents in upper layers of all the tested soils could be observed.

WIKLANDER (1973) and VoLEK (1974) warned of the acidification of soils due to acid precipitations in Scandinavia and Czechoslovakia, respectively. Judging by the results of this experiment it may be concluded that precipitations with a $\mathrm{pH}$ lower than 4 might have a very marked effect upon the acid leach of surface soil layers. It should be mentioned that this effect depends also upon the clay content of the soil, since in soil A (fine sand) the acidification was more significant than in soils B (loam) and C (clay loam).

Finally, it should be emphasized that leaching effects of percolating solutions with graduated acidity were studied in short-term experiments (approximately 10 days). However, it seems quite predictable that after a long-term extraction with acid precipitations the unfavourable effects upon the wash-out of some nutrients will be even more intensive and the soil acidization will further increase. Thus, the air pollution caused by gaseous immissions results in a significant impoverishment of some necessary plant nutrients in the upper soil layers. Should there be a marked decrease in soil fertility in future, it would be necessary to replace these losses at relatively high cost.

\section{Acknowledgments}

This study was made possible by a scholarship granted by the Finnish Ministry of Educa. tion. The author is very grateful to Professor A. Kaila for her useful suggestions and constructive criticism. Further, he would like to thank all the staff of the Department of Agricultural Chemistry, University of Helsinki, for their friendly assistance and valuable advice during his studies in Finland. 


\section{REFERENCES}

GoH, K. M. 1972. Comparison and evaluation of methods for including nitrate in the total nitrogen determination of soils. J. Sci. Fd. Agric. 23: 275-284.

KaIlA, A. 1962. Fixation of ammonium in Finnish soils. J. Sci. Agr. Soc. Finl. 34: 107-114.

- - 1965. Fixation of potassium in Finnish soils. J. Sci. Agr. Soc. Finl. 37: 116-126.

Korkman, J. 1970. Leaching of nutrients from mixed fertilizer in some Finnish soils. J. Sci. Agr. Soc. Finl. 42: 216-223.

ODÉN, S. 1968. The acidification of air and precipitation and its consequences on the natural environment. Ekologikommittén Bull. No 1., Stat. Naturvetenskapliga Forskningsråd. 23 p. Stockholm.

WiKLANDER, L. 1973-74. The acidification of soil by acid precipitation. Grundförbättring. 26, $4: 155-164$.

Ms received August 25, 1977.

\section{SELOSTUS ${ }^{1}$ )}

\section{Kivennäismaan läpi valuvan veden happamuuden vaikutus ravinteiden huuhtoutumiseen ja muutamiin maan kemiallisiin ominaisuuksiin.}

Františé Haman ${ }^{2}$ )

Helsingin yliopiston maanviljelyskemian laitos, 00710 Helsinki 71

Ravinteiden huuhtoutumista ja muutoksia maan eräissä ominaisuuksissa seurattiin laboratoriossa muoviin käärittyjen maapylväiden (korkeus $25 \mathrm{~cm}$, halkaisija $5.5 \mathrm{~cm}$ ) avulla. Tutkittavien muokkauskerroksesta otettujen maiden (hieta, hiue, hiuesavi) läpi valutettiin $300 \mathrm{ml}$ deionisoitua vettä ( $\mathrm{pH}$ 6) tai laimeita rikkihappoliuoksia $(\mathrm{pH} \mathrm{5,} \mathrm{pH} \mathrm{4,} \mathrm{pH} 3)$.

Maapylvåiden läpi tulleen veden kalium-, kalsium- ja magnesiumpitoisuus oli sitä korkeampi mitä happamampi huuhtova liuos oli. Varsinkin hiedasta liuos, jonka $\mathrm{pH}$ oli 5 tai alempi, aiheutti voimakkaan kationien huuhtoutumisen. Läpitulleessa vedessä oli hyvin vähän ammoniumtyppeä verrattuna muihin kationeihin tai nitraattityppeen. Huuhtovan liuoksen happamuus ei vaikuttanut ammonium- tai nitraattitypen pitoisuuteen lukuunottamatta hiuesaven läpi tullutta vettä, jonka nitraattipitoisuus oli sitä alempi mitä happamampi huuhtova liuos oli.

Happamat liuokset alensivat maapylväiden ylimmän $7.5 \mathrm{~cm}$ kerroksen $\mathrm{pH}$-arvoa, eniten hietapylväissä. Happamuuden lisääntyessä tämän pintakerroksen uuttuvien $(\ln \mathrm{KCl})$ kalsiumin ja magnesiumin pitoisuudet vähenivät.

1) Selostuksen laatinut A. Jaakkola

${ }^{2}$ ) Nykyinen osoite: Department of Agricultural Chemistry and Plant Nutrition, University of Agriculture, Brno, Czechoslovakia. 